\title{
Knowledge Management in PCS-enabled ports: an assessment of the barriers
}

\begin{abstract}
Literature lacks works that investigate Knowledge Management (KM) from an interdisciplinary point of view and that deepen barriers to KM in a Supply Chain context. Thus, with the purpose to cope with this dearth, we singled out 75 barriers to KM adoption and / or development by means of an in-depth up-todate systematic literature review. The review was conducted according to a review matrix we developed for steering the inquiry and for classifying its results in six clusters. By pointing out the similarities between KM Systems and Port Community Systems (PCSs), we assessed the relevance of these clusters in a PCS-enabled port area through a focus group. The main evidences show that strategic, organizational, and technological barriers could be the most relevant ones in this context, while other acknowledged barriers may be less important. These results provide a first contribution to the aforementioned shortages, and pave the way for further research on KM in logistics and in PCS-enabled port communities.
\end{abstract}

Keywords. Port Community System (PCS); Knowledge Management (KM); Supply Chain (SC); barriers; literature review.

\section{Introduction}

Scientific literature proposes a wealth of contributions concerning Knowledge Management (KM) or Supply Chain Management (SCM), while the relationship between these two broad topics has been much less investigated. Yet, knowledge practices may improve Supply Chain (SC) design (Norbis et al., 2013), and intra-organisational KM could foster the integration between demand-side and supply-side processes for a successful SCM (Esper et al., 2010). In a broader perspective, "the knowledge development is an important antecedent to supply chain efficiency" (Hult et al., 2004, p. 251). Knowledge sharing has been acknowledged as critical to the SC performance in collaborative networks (Cai et al., 2013; Malhotra et al., 2005). Specifically, the participation of logistics operations in a structured KM process improves logistics performance, both directly and indirectly (Fugate et al., 2009, 2012).

Nowadays, KM processes are affected by the recent digitalization trends and the developments in data sourcing and processing, with the potential exploitation of less-structured data or higher data volumes. The Big Data and Internet of Things (IoT) paradigms foster the current pervasiveness of technology, which may revolutionize design and management of SCs (Waller and Fawcett, 2013a) and of logistics in general (Wang et al., 2016). Despite this potential, the increased data generation from heterogeneous sources has led to new problems in data analysis (Fan et al., 2014) and, consequently, in how to handle a KM process for capitalizing the data in innovative and valuable forms of insight. In this context characterized by a better off data availability, firms willing to succeed should embed KM, information sharing, and collaboration within their SCM and logistics development (Waller and Fawcett, 2013b).

Port areas play a prominent role in these topical evolutions because of three reasons. First, ports mostly offer logistics services through considerable amounts of data-intensive transactions, dealing with considerable volumes of structured data, and they are starting to collect less structured data too, for instance by spread sensors (Fernández et al., 2016). Second, several port stakeholders, such as shippers and other actors, are putting pressure on the digitalisation of the transactions for more transparency and efficiency in their SCs (Meersman et al., 2016). Third, there is a current trend towards collaboration and innovation in the maritime SC through Information and Communication Technology (ICT) solutions (Carlan et al., 2016).

In order to address these issues and to facilitate information sharing within port communities, some ports are adopting, or already developed, a Port Community System (PCS). A PCS is an open electronic platform that enables the exchange of information among the port stakeholders - Port Authorities (PAs), terminals, maritime agencies, shippers, hauliers and so on - by managing and optimizing the main port processes, e.g. import and export, drawing upon a single database that avoids bilateral data transfer (van Baalen et al., 2008). Ports have to coordinate different kinds of flows with the purpose to integrate the perspectives of a variety of stakeholders, both public and private, in a global SC (Baron and Mathieu, 2013). The current technological landscape focuses on integrating different Information Systems (ISs) with new technologies that could enable a richer data collection for highly scalable platforms, using cloud computing to collect, store, and process data (Heilig and Voß, 2017). In this scenario, PCSs play an active role: on one hand, they put the basis for a stronger integration in the port SCM; on the other hand, they are harnessing the current technological focus. 
The typical transactions of a PCS (see table A.1 in Appendix) entail arranging and near real-time sharing of structured data through storage / retrieval and transfer activities, resulting in a potential decrease of the time length of port document procedures (Aydogdu and Aksoy, 2015). The nature of such activities is analogous to that of the typical KM activities, i.e. knowledge Creation, Storage / Retrieval, Transfer, and Application (Alavi and Leidner, 2001). Since KM activities are supported by Knowledge Management Systems (KMSs), this similarity suggests that PCSs could be framed as a KMS.

KM activities in ports are potentially enabled by PCSs, and PCS-enabled KM could allow to pursue the aforementioned collaborative trend we highlighted. Despite the need to investigate KM from an interdisciplinary point of view (Evangelista and Durst, 2015), very limited efforts have been spent in studying KM in maritime SCs. For instance, Eon-Seong and Dong-Wook (2010) present a conceptual framework for linking the effectiveness of knowledge acquisition to maritime logistics value. Instead, Liang et al. (2012) developed a quality function deployment approach to set the priority of KM solutions in an international Taiwanese port, but the scope of such work does not consider a holistic perspective of an extended port community.

Cerchione and Esposito (2016) draw attention on the dearth of papers investigating the barriers to KM in SC. Two of the most extensive contributions concerning KM barriers in SC are Patil and Kant (2014a, 2014b). Patil and Kant (2014a) identify and rank a set of solutions for overcoming some barriers to KM adoption in SC collected from the extant literature. Patil and Kant (2014b) single out and prioritize 28 barriers to KM adoption in SC on the basis of a literature review and expert's opinion. Notwithstanding, the scope of these works is limited to KM adoption only, and it does not consider KM development. Moreover, to our best knowledge, despite the above-discussed importance of KM and KMS to port areas, scientific literature lacks manuscripts tackling barriers to KM in maritime contexts and in PCS-enabled communities in particular.

Accordingly, the purpose of this paper it to provide an answer to the following research question: "What are the most relevant barriers to Knowledge Management in ports areas supported by a Port Community System?". From a scientific perspective, the attainment of this objective could fill the literature gaps we highlighted, and could provide an up-to-date overview of the barriers to the whole KM process, without limiting the inquiry to KM adoption only. From a managerial perspective, the increased awareness about KM barriers in PCS-enabled port areas may help practitioners to plan more sharp and effective actions to overcome them, and to carry on enhanced KM processes.

In order to fulfil the purpose we set, we built up a review matrix for steering a thorough literature review on $\mathrm{KM}$ barriers, and for classifying and discussing its results in six clusters. The relevance of each cluster was assessed through a Focus Group (FG) run with experts linked to a Mediterranean PCS-enabled PA, and the conclusions were drawn consistently.

This work consists of five sections: after the introduction, we present the Research design section; the Barriers to KM Adoption and Development section contains both classification and critical discussion of the results from the literature review; Results and discussion shows and analyses the main evidences from the FG; finally, Conclusions depicts implications and limitations of this work, and proposes suggestions for further research.

\section{Research design}

With the purpose to answer to the research question, we adopted the following approach: (1) development of an ad-hoc review matrix for identifying and classifying the KM barriers; (2) development of an in-depth literature review about KM barriers; (3) running of a FG for assessing applicability and relevance of the barriers in a PCS-enabled PA, and for potentially identifying new barriers.

1. Review matrix. In order to provide a structure for identifying and classifying the KM barriers, we built an ad-hoc review matrix. The rows define six possible clusters of KM barriers. Five of them strategic, organisational, technological, cultural, and individual - were borrowed from the classification framework of KM barriers by Patil and Kant (2014a). Since theoretical developments in KM are affected by the types of knowledge (Alavi and Leidner, 2001), we took into consideration a sixth cluster - knowledge barriers - for including such perspective in our matrix. Thus, we characterize the six clusters as follows:

- Strategic barriers: hindrances linked to corporate decision-making and to strategic planning. 
- Organisational barriers: obstacles tied to the four organisation design parameters by Mintzberg (1993) - design of positions, design of superstructure, design of lateral linkages, and design of decision-making system.

- Technological barriers: hampering factors that concern the hardware and software infrastructure and the activities that allow its full exploitation.

- Cultural barriers: hurdles related to culture in organisations, defined as "(a) a pattern of basic assumptions, (b) invented, discovered, or developed by a given group, (c) as it learns to cope with its problems of external adaptation and internal integration, (d) that has worked well enough to be considered valid and, therefore (e) is to be taught to new members as the (f) correct way to perceive, think, and feel in relation to those problems" (Schein, 1990, p. 111).

- Individual barriers: inhibition factors associated with the individual standpoint within an organisation or among different organisations. They refer to the perspective of individuals and to their perceptions, which are influenced by past experiences and personal values and attitudes.

- Knowledge barriers: hindrances related to the knowledge characteristics.

The columns depict which part(s) of the KM process is (are) affected by the barriers. In line with several authors (e.g. Bhatt, 2000; Cerchione and Esposito, 2016; Wiig, 1997; Wong and Aspinwall, 2005, 2006), we split the KM process into Knowledge Management Adoption (KMA) and Knowledge Management Development (KMD). KMA concerns the introduction of KM principles in a firm, while KMD encompasses the KM activities: Creation (C), Storage / Retrieval (S/R), Transfer (T), and Application (A) of knowledge, defined in accordance to Alavi and Leidner (2001).

2. Literature review. Scientific literature on KM is very extensive. Thus, with the purpose of identifying the barriers linked to KM, a general inquiry could have resulted in an unmanageable and low-focused outcome. Consequently, we decided to develop a literature review on the KM reviews: in this way, the selected reviews provided a basis of papers which to elicit the barriers from.

According to the review principles by Webster and Watson (2002), we carried the literature review out in six steps: (I) identification of keywords and search strings; (II) definition of the time window; (III) selection of the citation database(s); (IV) selection of the disciplines / topics; (V) refinement of the results through a multi-staged skimming process; (VI) review of the relevant papers. Table 1 shows the protocol for the literature review, while table 2 details the steps we followed for skimming the papers.

Table 1. Protocol for the literature review

\begin{tabular}{|c|c|c|c|}
\hline PARAMETER & \multicolumn{2}{|c|}{ DETAIL } & JUSTIFICATION \\
\hline SOURCES & Scopus & $\begin{array}{l}\text { Institute for Scientific } \\
\text { Information (ISI) }\end{array}$ & $\begin{array}{l}\text { Scopus and ISI Web of Science }(\text { WoS }) \text { are } \\
\text { recognized as the two most large abstract } \\
\text { and citation databases of peer-reviewed } \\
\text { literature }\end{array}$ \\
\hline KEYWORDS & $\begin{array}{c}\text { Review in Title, } \\
\text { Abstract, and Keywords } \\
\text { AND "Knowledge } \\
\text { management" in Title. }\end{array}$ & $\begin{array}{c}\text { Review in Topic AND } \\
\text { "Knowledge Management" in } \\
\text { Title. }\end{array}$ & $\begin{array}{l}\text { Keywords were chosen according to the } \\
\text { objective of this review; "Knowledge } \\
\text { Management" was restricted to the Title for } \\
\text { investigating the most focused papers; } \\
\text { Review was restricted to Title, Abstract, and } \\
\text { Keywords (Topic for ISI) because it is a } \\
\text { methodological term: papers involving a } \\
\text { review often include it in the abstract or in } \\
\text { the keywords, but not in the title. }\end{array}$ \\
\hline DISCIPLINES & $\begin{array}{l}\text { Business, Management } \\
\text { and Accounting; } \\
\text { Computer Science; } \\
\text { Engineering; Social } \\
\text { Sciences; Decision } \\
\text { Sciences; Economics, } \\
\text { Econometrics and } \\
\text { Finance. }\end{array}$ & $\begin{array}{l}\text { Management; Information } \\
\text { science library science; } \\
\text { Computer science information } \\
\text { systems; Business; Operations } \\
\text { research management science; } \\
\text { Economics; Engineering } \\
\text { multidisciplinary; Computer } \\
\text { science interdisciplinary } \\
\text { application. }\end{array}$ & $\begin{array}{l}\text { Disciplines were selected according to their } \\
\text { fit with the research objective }\end{array}$ \\
\hline
\end{tabular}




\begin{tabular}{clc}
\hline TIME WINDOW & All-time & Comprehensiveness of the inquiry \\
\hline TYPE OF ARTICLE & Journal & ---- \\
\hline LANGUAGE & English & --- \\
\hline RESULTS OF THE QUERY & $\begin{array}{l}464 \text { from Elsevier, 202 from ISI. The number of total papers is lower } \\
\text { than 666 because Scopus and WoS share several journals. }\end{array}$ \\
\hline
\end{tabular}

Table 2. Skimming steps

\begin{tabular}{ccc}
\hline $\begin{array}{c}\text { SKIMMing } \\
\text { PHASE }\end{array}$ & $\begin{array}{c}\text { CRITERIA FOR FIT } \\
\text { EVALUATION }\end{array}$ & $\begin{array}{c}\text { NUMBER OF RETAINED } \\
\text { PAPERS PER STEP }\end{array}$ \\
\hline STEP 1 & $\begin{array}{c}\text { Redundancy; Title, abstract, } \\
\text { and keywords }\end{array}$ & 19 \\
\hline STEP 2 & Full body & 4 \\
\hline
\end{tabular}

Jointly, the authors extracted the barriers from the four selected reviews - Alavi and Leidner (2001), Cerchione et al. (2015), Lin et al. (2012), Ragab and Arisha (2013) - and analysed the references from all the 19 reviews for expanding both the level of detail and the scope of the inquiry. The references were evaluated according to the aforementioned six-step research and skimming protocol, and other barriers were extracted from the additional papers. Hence, the authors were randomly divided in two couples, which independently assigned the barriers to the review framework. The results were compared, critically discussed, and re-arranged until convergence. The classification was further revised and validated by an independent senior researcher, which has not been involved in the authorship of this paper. Her background is consistent with both the topic of this manuscript and with qualitative research methodologies.

3. Focus group. In order to assess the relevance of the six clusters of barriers to KM in a PCS-enabled port area, a FG study was conducted according to Kitzinger $(1994,1995)$. On the basis of a list of the PCS-enabled ports, obtained by means of the International Port Community Systems Association see http://www.ipcsa.international/ for further details - we selected a small-to-medium Mediterranean port according to a geographical proximity criterion. No criteria about the dimension of the port were considered because port communities support their processes through a PCS only if their business volume justifies the implementation project and if the relationships among the port stakeholders and the PA are sufficiently numerous.

We chose to rely on the FG methodology because port communities involve relationships among several different stakeholders, and a selected FG is suitable for highlighting them: the group dynamics of a FG, if aligned with the research purpose, provide perspective, views, observations, and comments that are less accessible through questionnaires and one-to-one interviews (Kitzinger, 1994; Watts and Ebbutt, 1987). In addition, the FG methodology points out the respondents' attitudes and priorities (Kitzinger, 1994), and establishing priority and relevance (of the clusters of KM barriers) was exactly the purpose of our inquiry.

Since FG studies use theoretical sampling "whereby participants are selected to reflect a range of total study population" (Kitzinger, 1995, p. 300), we initially decided to involve in the FG one informant from all the main port stakeholders that utilise the PCS - e.g. terminals, freight forwarders, customs house agents, and so on. Yet, during a kick-off meeting with three informants from the PA, conducted in the end of November 2016 for introducing the research question and for providing all the further details, we were advised against the FG structure we hypothesized, because of two reasons. First, when the PCS was released in 2011/2012, several stakeholders had not any IS, and they were managing their business on paper. Most of them have adopted the PCS for avoiding a severe business disruption but, despite multiple port community events for introducing the PCS to the port actors, they have kept reluctance towards this system. Second, most stakeholders exploit only some functionalities of the PCS, and they do have a holistic point of view neither on the PCS nor on the port processes. Hence, the PA suggested to select a lower number of informants according to their competences and knowledge about both the behaviour and the requirements of other port actors. 
As "the ideal group size is between four and eight people" (Kitzinger, 1995, p. 301), the FG consisted of:

- A junior researcher, knowledgeable in port processes and logistics, which is the main author of this manuscript. Given his previous experience in conducting qualitative inquiries, he covered the role of facilitator, which is typical in FGs for stimulating and addressing the group discussion (Kitzinger, 1995). The presence of a researcher within a FG is common (Kitzinger, 1995), and he was chosen also because he was the only author competent in maritime dynamics: this choice reduced the potential bias that would have occurred by selecting him as active participant in the FG.

- Three senior researchers, whose main research area has been logistics, management information systems, and business process management, respectively. They were selected according to the fit between their background and the context of analysis, since PCS-based ports mostly offer logistics services by means of IS-enabled business processes. The role of the senior researchers was twofold: (I) leveraging their background to help the other respondents to figure out the nature of the six clusters of barriers; and (II) to exploit their own experience and anecdotes for further fostering the group dynamics, which is one of the main points of strength of the FG methodology.

- An expert, from the PA, on management and streamlining of port business processes, which was also a key user during the PCS implementation project.

- A software developer working for the company which development and maintenance of the PCS was outsourced to. He has been dedicated to the port platform and has been its main programmer since its implementation.

Since two of the three senior researchers are co-authors of this manuscript, it was necessary to cope with the risk of a possible bias. This issue was tackled by taking into account two aspects. First, the absence of scientific literature on KM in PCS-enabled ports drastically reduced the risk to have preconceived opinions about the relevance of some clusters of barriers over other ones. Second, the facilitator led the FG on the basis of an ad-hoc summary, whose structure was partially borrowed by the interim case summary by Miles et al. (2013). The ad-hoc summary consisted in an agenda for steering the data collection during the FG. Its content was a bullet list about the main themes to cover within the discussion, based on the results from the literature review, for allowing the facilitator to keep the group discussion focused without diverging from its purpose and for possibly avoiding any biased interaction.

The FG discussion was carried out on the fifth of December 2016, and it lasted three hours and half, split in two sessions. It was focused on the six clusters of the review framework and, hence, on the barriers to the KM process. The whole discussion was recorded, transcribed, and the most relevant evidences were streamlined through the vignettes method by Miles et al. (2013). After a week, the outcome was discussed and analysed with all the components of the FG for reaching consensus. Thus, according to the final results, the conclusions of this work were drawn.

\section{Barriers to KM Adoption and Development}

We identified seventy-five (75) barriers, divided in decreasing order as follows: nineteen (19) organisational barriers, seventeen (17) individual barriers, fourteen (14) technological barriers, eleven (11) strategic barriers, eight (8) cultural barriers, and six (6) knowledge barriers. Table 3 shows their classification within the review matrix. Thirteen barriers potentially affect the whole KM process, and other thirteen barriers hamper KMD only. Although some barriers may seem double-barrelled, their classification always refer to a different domain - e.g. lack of confidence in benefits from KM (S11) compared to unrealistic expectations from KMSs (T13). In addition, some barriers may relate to similar concepts, but they underline different nuances $-e . g$. T8 and T9 concern the IS use while describing different aspects. Because of reasonable space limits, we were not able to report all these different interpretations, but the references in table 3 address them directly.

As specified at the bottom of table 3, some barriers were framed as Small-and-Medium-Enterprise (SME)specific or SC-related by the pertinent authors. It is important to note that some barriers - e.g. Lack of leadership (O10) - were explicitly considered as SC-related only by some authors, while other academics conceived them as pertaining a single firm. 
In the following sub-sections, we discuss the main findings for each cluster.

\section{Strategic barriers}

The most cited strategic barrier is the need to comply with time and financial constraints (e.g. Lin et al., 2012; Zhao et al., 2012). KM practices can be expensive and time-consuming (Riege, 2005) but, despite an adequate financial commitment to support knowledge flows and collaboration, KM strategies need to be carefully planned (Blumenberg et al., 2009; Raisinghani \& Meade, 2005), and may still fail because of a low integration between them and the overall goals and strategy of the firm (Lang, 2001).

Often, benefits from KM are hampered by the lack of integration of KM with other business processes (e.g. Nätti and Ojasalo, 2008) or by the wrong idea that an Information-Technology-based approach to KM could lead to a positive outcome of the whole initiative (Ragab and Arisha, 2013). A possible cause of such issues could be the low understanding of both what KM is (e.g. Aziz and Sparrow, 2011) and of what value it might create (Lang, 2001), which heavily affects KMA and that could generate unreliable expectations about KM. This low awareness spreads downstream on KMD, making knowledge creation and application discontinuous across the different levels of the firm (Lang, 2001).

SMEs seem to be more concerned about barriers to KMA, like difficulties in planning and prioritizing such investment and in obtaining a believable Return on Investment from it (Nunes et al., 2006). Yet, while SMEs typically face KM barriers like lack of managerial support, lack of confidence in benefits from KM, and concerns about preserving their information from opportunistic behaviours, they might be less worried about low availability of financial resources than in past (Cerchione et al., 2015).

\section{Organisational barriers}

In general, lack of leadership (e.g. Lin et al., 2008; Rosen et al., 2007) and insufficient communication with the employees about the benefits that could likely stem from a KM initiative (e.g. Ahn et al., 2005; Alavi et al., 2005) are the only organisational barriers that affect the KM process as a whole, while almost all the other organisational may barriers address KMD only.

One of the main hurdles to KMD is the organisational structure that, most times, considers knowledge hoarding as acceptable and does not foster knowledge sharing (e.g. Lam and Lambermont-Ford, 2010; Ling, 2011). This often happens due to reward systems (e.g. Henry et al., 2007; Rosen et al., 2007; Shaw and Edwards, 2005) or specific organisational norms (Alavi and Leidner, 2001) that do not promote the sharing of insights. Moreover, excessive size of business units (Lin et al., 2012), lack of their coordination (Riege, 2005), and the competitive dynamics among them or among functional areas or subsidiaries (Cheng et al., 2008) hamper the development of a KM process. Organisational structures that face such hindrances could not provide sufficient support in collecting, managing, and communicating lessons from past experiences for boosting a learning effect. In addition, strong hierarchies, in which formal power strongly affects work relationships and tolerance on mistakes, worsen knowledge activities and restrict knowledge flows to a bottom-up direction (Riege, 2005). Restrictions to specific directions of knowledge flows also affect KM among different actors of the SC (e.g. Al-Mutawah et al., 2009; Shih et al., 2012), and asymmetries in the knowledge about the role of other SC members could hinder knowledge creation, transfer, and application (Aziz and Sparrow, 2011; Nätti and Ojasalo, 2008). 
Table 3. Classification of the KM barriers

\begin{tabular}{|c|c|c|c|c|c|c|c|c|}
\hline \multirow{2}{*}{$\begin{array}{c}\text { Main } \\
\text { Criterion }\end{array}$} & \multirow{2}{*}{ Code } & \multirow{2}{*}{ Barrier } & \multirow{2}{*}{ KMA } & \multicolumn{4}{|c|}{ KMD } & \multirow{2}{*}{ References } \\
\hline & & & & $\mathbf{C}$ & $\mathbf{S} / \mathbf{R}$ & $\mathbf{T}$ & $\mathbf{A}$ & \\
\hline \multirow{11}{*}{ Strategy } & S1 & IT-based approach to KM & & $\bar{x}$ & $\mathrm{x}$ & $\mathrm{x}$ & $\mathrm{x}$ & Ragab \& Arisha (2013) \\
\hline & S2 & Insufficient linkage between KM and corporate strategy & $\mathrm{x}$ & $\mathrm{x}$ & $\mathrm{x}$ & $\mathrm{x}$ & $\mathrm{x}$ & $\begin{array}{l}\text { Lang (2001); Raisinghani \& Meade (2005) }{ }^{\dagger} \text {; Riege (2005); } \\
\text { Blumenberg et al. (2009) }\end{array}$ \\
\hline & S3 & Lack of holism in KM efforts & & $\mathrm{x}$ & & & $\mathrm{x}$ & Lang (2001) \\
\hline & S4 & Time and resource constraints & $\mathrm{x}$ & $\mathrm{x}$ & $\mathrm{x}$ & $\mathrm{x}$ & $\mathrm{x}$ & $\begin{array}{l}\text { Riege (2005); Ahmad \& Daghfous (2010) } ; \text {; Lin et al. (2012); } \\
\text { Zhao et al. (2012) }{ }^{\dagger} \text {; Cerchione et al. (2015)* }\end{array}$ \\
\hline & S5 & Lack of integration of KM with existing processes & & $\mathrm{x}$ & $\mathrm{x}$ & $\mathrm{x}$ & $\mathrm{x}$ & $\begin{array}{l}\text { Nätti \& Ojasalo (2008) }{ }^{\dagger} \text {; Ahmad \& Daghfous }(2010)^{\dagger} \text {; Cerchione } \\
\text { et al. }(2015)^{*}\end{array}$ \\
\hline & S6 & Lack of clear understanding of KM & $\mathrm{x}$ & & & & & Aziz \& Sparrow $(2011)^{\dagger}$; Shih et al. $(2012)^{\dagger}$ \\
\hline & S7 & $\begin{array}{l}\text { Lower priority given to long-term investments of managerial } \\
\text { effort against short-term investments }\end{array}$ & $\mathrm{x}$ & & & & & Nunes et al. (2006)* \\
\hline & S8 & Difficulties in obtaining a believable Return on Investment & $\mathrm{x}$ & & & & & Nunes et al. $(2006)^{*}$ \\
\hline & S9 & Lack of confidence in benefits from the KM process & $\mathrm{x}$ & $\mathrm{x}$ & & & $\mathrm{x}$ & Lang (2001); Cerchione et al. (2015)* \\
\hline & S10 & Lack of support from the top management & $\mathrm{x}$ & & & & & Cerchione et al. (2015)* \\
\hline & $\mathrm{S} 11$ & Protection of critical information & $\mathrm{x}$ & & & & & Cerchione et al. (2015)* \\
\hline \multirow{12}{*}{ Organisation } & O1 & Close ties in communities & & $\mathrm{x}$ & & & & Robertson et al. (1996) \\
\hline & $\mathrm{O} 2$ & $\begin{array}{l}\text { Lack of rewards or recognition for contributing and sharing } \\
\text { insights }\end{array}$ & & & $\mathrm{x}$ & $\mathrm{x}$ & & $\begin{array}{l}\text { Brown \& Duguid (1998); Riege (2005); Shaw \& Edwards } \\
\text { (2005); Henry et al. (2007); Rosen et al. (2007); Lin et al. } \\
\text { (2008); Hutzschenreuter \& Horstkotte (2010) } ; \text {; Lam \& } \\
\text { Lambermont-Ford (2010); }\end{array}$ \\
\hline & O3 & $\begin{array}{l}\text { Lack of balance of the knowledge flow between the provider } \\
\text { (source) and the knowledge seeker }\end{array}$ & & & & $\mathrm{x}$ & & Alavi \& Leidner (2001); Riege (2005) \\
\hline & $\mathrm{O} 4$ & $\begin{array}{l}\text { Lack of organisational structure and norms that foster knowledge } \\
\text { sharing and that proscribes knowledge hoarding }\end{array}$ & & $\mathrm{x}$ & $\mathrm{x}$ & $\mathrm{x}$ & & $\begin{array}{l}\text { Alavi \& Leidner (2001); Riege (2005); Nätti \& Ojasalo (2008) }{ }^{\dagger} \text {; } \\
\text { Ahmad \& Daghfous (2010) }{ }^{\dagger} \text {; Lam \& Lambermont-Ford (2010); } \\
\text { Ling (2011) }\end{array}$ \\
\hline & O5 & $\begin{array}{l}\text { Knowledge asymmetries due to an approach to knowledge } \\
\text { focused on teaching instead of learning }\end{array}$ & & & & $\mathrm{x}$ & & Becker (2001) \\
\hline & O6 & $\begin{array}{l}\text { Difficult internal relationships among employees / business units } \\
\text { / functions }\end{array}$ & & & & $\mathrm{x}$ & & Szulanski (1996); Bock et al. (2005) \\
\hline & O7 & Poor physical work environment & & $\mathrm{x}$ & $\mathrm{x}$ & $\mathrm{x}$ & $\mathrm{x}$ & Riege (2005); Lin et al. (2012) \\
\hline & O8 & Lack of spaces to share or generate knowledge & & $\mathrm{x}$ & & $\mathrm{x}$ & & $\begin{array}{l}\text { Riege (2005); Hutzschenreuter \& Horstkotte (2010) }{ }^{\dagger} \text {; Lin et al. } \\
\text { (2012) }\end{array}$ \\
\hline & O9 & Excessive size of business units & & $\mathrm{x}$ & & $\mathrm{x}$ & & Riege (2005); Lin et al. (2012) \\
\hline & $\mathrm{O} 10$ & Lack of leadership & $\mathrm{x}$ & $\mathrm{x}$ & $\mathrm{x}$ & $\mathrm{x}$ & $\mathrm{x}$ & $\begin{array}{l}\text { Bandyopadhyay \& Pathak (2007) })^{\dagger} \text { Rosen et al. (2007); Lin et al. } \\
\text { (2008) }\end{array}$ \\
\hline & O11 & $\begin{array}{l}\text { Lack of coordination between units due to geographical, context } \\
\text { and competitiveness reasons }\end{array}$ & & $\mathrm{x}$ & $\mathrm{x}$ & $\mathrm{x}$ & $\mathrm{x}$ & Riege (2005) \\
\hline & $\mathrm{O} 12$ & $\begin{array}{l}\text { Lack of intangible mechanisms like unscheduled meetings, } \\
\text { informal seminars, coffee break conversations }\end{array}$ & & $\mathrm{x}$ & & $\mathrm{x}$ & & $\begin{array}{l}\text { Riege (2005); He et al. (2009) Hutzschenreuter \& Horstkotte } \\
(2010)^{\dagger}\end{array}$ \\
\hline
\end{tabular}




\begin{tabular}{|c|c|c|c|c|c|c|c|c|}
\hline & $\mathrm{O} 13$ & $\begin{array}{l}\text { Lack of adequate communication with employees about the } \\
\text { benefits }\end{array}$ & $\mathrm{x}$ & $\mathrm{x}$ & $\mathrm{x}$ & $\mathrm{x}$ & $\mathrm{x}$ & Ahn et al. (2005); Alavi et al. (2005); Riege (2005) \\
\hline & O14 & $\begin{array}{l}\text { Use of strong hierarchy, position-based status, formal power, and } \\
\text { low tolerance on mistakes }\end{array}$ & & $\mathrm{x}$ & $\mathrm{x}$ & $\mathrm{x}$ & $\mathrm{x}$ & Riege (2005) \\
\hline & O15 & $\begin{array}{l}\text { Insufficient support in capturing, evaluating and communicating } \\
\text { lessons from past mistakes for fostering a learning effect }\end{array}$ & $\mathrm{x}$ & $\mathrm{x}$ & $\mathrm{x}$ & $\mathrm{x}$ & $\mathrm{x}$ & Riege (2005); Cerchione et al. (2015)* \\
\hline & O16 & $\begin{array}{l}\text { Low priority in knowledge retention of highly skilled / } \\
\text { experienced staff }\end{array}$ & & & $\mathrm{x}$ & & & Riege (2005); Fletcher \& Polychronakis (2007) ${ }^{\dagger}$ \\
\hline & $\mathrm{O} 17$ & $\begin{array}{l}\text { External competitiveness within business units, functional areas, } \\
\text { or subsidiaries }\end{array}$ & & & $\mathrm{x}$ & $\mathrm{x}$ & & Riege (2005); Cheng et al. (2008) ${ }^{\dagger}$ \\
\hline & $\mathrm{O} 18$ & $\begin{array}{l}\text { Restriction to specific directions of communication and } \\
\text { knowledge flow }\end{array}$ & & $\mathrm{x}$ & & $\mathrm{x}$ & & $\begin{array}{l}\text { Riege (2005); Kasper et al. (2008) }{ }^{\dagger} \text {; Al-Mutawah et al. }(2009)^{\dagger} \text {; } \\
\text { Shih et al. (2012) }\end{array}$ \\
\hline & O19 & Lack of adequate knowledge of functioning of other SC members & & $\mathrm{x}$ & & $\mathrm{x}$ & $\mathrm{x}$ & Nätti \& Ojasalo (2008) $)^{\dagger}$; Aziz \& Sparrow (2011) ${ }^{\dagger}$ \\
\hline \multirow{14}{*}{ Technology } & $\mathrm{T} 1$ & $\begin{array}{l}\text { Knowledge retrieval mechanisms that are hard to remember and } \\
\text { that do not avoid information overload }\end{array}$ & & & $\mathrm{x}$ & & & Alavi \& Leidner (2001) \\
\hline & $\mathrm{T} 2$ & $\begin{array}{l}\text { Greater likelihood of knowledge misuse due to excessive readily } \\
\text { available knowledge }\end{array}$ & & & $\mathrm{x}$ & & $\mathrm{x}$ & Alavi \& Leidner (2001) \\
\hline & $\mathrm{T} 3$ & Inhibition effect on learning due to KMSs & & $\mathrm{x}$ & & & $\mathrm{x}$ & Cole (1998) \\
\hline & T4 & $\begin{array}{l}\text { Lack of sharing mechanisms such as telephones, conference } \\
\text { rooms or computer networks }\end{array}$ & & & & $\mathrm{x}$ & $\mathrm{x}$ & He et al. (2009) \\
\hline & T5 & Failure to develop a transactive memory system & & & $\mathrm{x}$ & & & Rosen et al. (2007) \\
\hline & $\mathrm{T} 6$ & Lack of familiarity and experience with the new ISs & & $\mathrm{x}$ & $\mathrm{x}$ & $\mathrm{x}$ & $\mathrm{x}$ & Riege (2005); Lin et al. (2012) \\
\hline & $\mathrm{T} 7$ & Lack of training concerning the new ISs & & $\mathrm{x}$ & $\mathrm{x}$ & $\mathrm{x}$ & $\mathrm{x}$ & Riege (2005); Lin et al. (2012) \\
\hline & T8 & Lack of integration between ISs and business processes & & $\mathrm{x}$ & $\mathrm{x}$ & $\mathrm{x}$ & $\mathrm{x}$ & Brandon \& Hollingshead (2004); Riege (2005) \\
\hline & T9 & Lack of compatibility among different ISs & & $\mathrm{x}$ & $\mathrm{x}$ & $\mathrm{x}$ & $\mathrm{x}$ & Lin et al. (2012) \\
\hline & $\mathrm{T} 10$ & Lack of trust in system's security & $\mathrm{x}$ & $\mathrm{x}$ & $\mathrm{x}$ & $\mathrm{x}$ & $\mathrm{x}$ & $\begin{array}{l}\text { Gunasekaran \& Ngai }(2004)^{\dagger} ; \text { Kumar \& Thondikulam }(2006)^{\dagger} ; \\
\text { Lin et al. (2012) }\end{array}$ \\
\hline & $\mathrm{T} 11$ & Lack of technical support & & $\mathrm{x}$ & $\mathrm{x}$ & $\mathrm{x}$ & $\mathrm{x}$ & Riege (2005); Hutzschenreuter \& Horstkotte (2010) ${ }^{\dagger}$ \\
\hline & T12 & $\begin{array}{l}\text { Lack of communication and demonstration of the benefits in } \\
\text { using the new ISs over the previous ones }\end{array}$ & $\mathrm{x}$ & $\mathrm{x}$ & $\mathrm{x}$ & $\mathrm{x}$ & $\mathrm{x}$ & Riege (2005) \\
\hline & T13 & Unrealistic expectations about KMSs & $\mathrm{x}$ & $\mathrm{x}$ & $\mathrm{x}$ & $\mathrm{x}$ & $\mathrm{x}$ & Riege (2005) \\
\hline & $\mathrm{T} 14$ & Lack of technological infrastructure to adopt KM & $\mathrm{x}$ & $\mathrm{x}$ & $\mathrm{x}$ & $\mathrm{x}$ & $\mathrm{x}$ & Wong \& Wong (2011) ${ }^{\dagger}$ \\
\hline \multirow{7}{*}{ Culture } & $\mathrm{C} 1$ & Lack of sufficient context detail in storing knowledge & & & $\mathrm{x}$ & & $\mathrm{x}$ & Alavi \& Leidner (2001) \\
\hline & $\mathrm{C} 2$ & Lack of a shared cultural meaning of KM activities & $\mathrm{x}$ & $\mathrm{x}$ & $\mathrm{x}$ & $\mathrm{x}$ & $\mathrm{x}$ & Beesley \& Cooper (2008) \\
\hline & $\mathrm{C} 3$ & $\begin{array}{l}\text { Inadequate care of organizational relationships that promote } \\
\text { knowledge creation }\end{array}$ & & $\mathrm{x}$ & & & $\mathrm{x}$ & Lang (2001) \\
\hline & $\mathrm{C} 4$ & Lack of an organisational culture that fosters knowledge sharing & & & & $\mathrm{x}$ & & $\begin{array}{l}\text { Riege (2005); Nätti \& Ojasalo (2008); Hutzschenreuter \& } \\
\text { Horstkotte (2010) })^{\dagger} \text {; Ling (2011); Shih et al. (2012) }{ }^{\dagger}\end{array}$ \\
\hline & $\mathrm{C} 5$ & Uncertainty avoidance & & & & $\mathrm{x}$ & & Chen et al. (2010); Wang et al. (2011) \\
\hline & C6 & Power distance & & & & $\mathrm{x}$ & & Chen et al. (2010); Wang et al. (2011) \\
\hline & $\mathrm{C} 7$ & $\begin{array}{l}\text { Differences in national or ethnic background, values, beliefs, and } \\
\text { cultural characteristics }\end{array}$ & & $\mathrm{x}$ & $\mathrm{x}$ & $\mathrm{x}$ & $\mathrm{x}$ & $\begin{array}{l}\text { Riege (2005); Rosen et al. (2007); Lin et al. (2008); Myers \& } \\
\text { Cheung (2008) }{ }^{\dagger} \text {; Nätti \& Ojasalo (2008); Wong \& Wong (2011) }\end{array}$ \\
\hline
\end{tabular}




\begin{tabular}{|c|c|c|c|c|c|c|c|c|}
\hline & $\mathrm{C} 8$ & Lack of trust and commitment of SC members & $\mathrm{x}$ & & & $\mathrm{x}$ & & $\begin{array}{l}\text { Spekman et al. (2002) })^{\dagger} \text {; Maqsood et al. (2007); Vithessonthi } \\
\left.(2008)^{\dagger} \text {; Samuel et al. (2011) }\right)^{\dagger} \text {; Shih et al. (2012) }\end{array}$ \\
\hline \multirow{17}{*}{ Individual } & I1 & Distrusting the source of knowledge (NIH syndrome) & & & & $\mathrm{x}$ & $\mathrm{x}$ & Davenport \& Prusak (1998); Riege (2005); Lin et al. (2008) \\
\hline & $\mathrm{I} 2$ & Lack of time or opportunity to share and to apply knowledge & & & & $\mathrm{x}$ & $\mathrm{x}$ & $\begin{array}{l}\text { Davenport \& Prusak (1998); Riege (2005); Lin et al. (2008); } \\
\text { Levy et al. (2010); Aziz \& Sparrow (2011) }\end{array}$ \\
\hline & I3 & Risk aversion, linked to firm's low tolerance on mistakes & & & & & $\mathrm{x}$ & Davenport \& Prusak (1998) \\
\hline & I4 & $\begin{array}{l}\text { Pre-existing knowledge and cognitive "routines" that can create a } \\
\text { barrier to search, absorption, and application of new knowledge }\end{array}$ & & & $\mathrm{x}$ & $\mathrm{x}$ & $\mathrm{x}$ & Alavi (2000) \\
\hline & I5 & Lack of willingness to share knowledge & & & & $\mathrm{x}$ & & Lin et al. (2008); Garcia-perez \& Ayres (2010) \\
\hline & I6 & $\begin{array}{l}\text { Fear of losing the individual advantage, reducing chances of } \\
\text { promotion and benefiting the others with whom knowledge was } \\
\text { shared }\end{array}$ & & & & $\mathrm{x}$ & & $\begin{array}{l}\text { Riege (2005); Shaw \& Edwards (2005); Lin et al. (2008); Renzl } \\
\text { (2008); Chou \& Passerini, (2009) ; Hislop (2009) }\end{array}$ \\
\hline & I7 & $\begin{array}{l}\text { Fear that contributing to the company's KMS could indirectly } \\
\text { cause job loss }\end{array}$ & $\mathrm{x}$ & $\mathrm{x}$ & $\mathrm{x}$ & $\mathrm{x}$ & $\mathrm{x}$ & Damodaran \& Olphert (2000); Riege (2005); He et al. (2009) \\
\hline & I8 & Fear of publishing something confidential & & & & $\mathrm{x}$ & & Paroutis \& Saleh (2009) \\
\hline & I9 & Unawareness of what knowledge has to be shared & & & & $\mathrm{x}$ & & Lin et al. (2008); Levy et al. (2010) \\
\hline & $\mathrm{I} 10$ & Lack of trust in people & & & & $\mathrm{x}$ & & Riege (2005); Rosen et al. (2007); He et al. (2009) \\
\hline & I11 & Lack of absorptive capability & & & & $\mathrm{x}$ & $\mathrm{x}$ & Szulanski (1996); Chou et al. (2007); Lin et al. (2008) \\
\hline & I12 & Lack of retentive capacity & & & $\mathrm{x}$ & $\mathrm{x}$ & $\mathrm{x}$ & Lin et al. (2012) \\
\hline & I13 & $\begin{array}{l}\text { Unrealistic expectations of employees and individual misfits with } \\
\text { personal needs }\end{array}$ & $\mathrm{x}$ & $\mathrm{x}$ & $\mathrm{x}$ & $\mathrm{x}$ & $\mathrm{x}$ & Shin (2004) \\
\hline & I14 & Differences in experience, age, gender, and education levels & & $\mathrm{x}$ & $\mathrm{x}$ & $\mathrm{x}$ & $\mathrm{x}$ & Riege (2005) \\
\hline & I15 & $\begin{array}{l}\text { Poor verbal / written communication, interpersonal, and } \\
\text { computer skills }\end{array}$ & & & $\mathrm{x}$ & $\mathrm{x}$ & $\mathrm{x}$ & $\begin{array}{l}\text { Riege (2005); Joshi et al. (2007) }{ }^{\dagger} \text {; Hutzschenreuter \& Horstkotte } \\
\text { (2010) }\end{array}$ \\
\hline & I16 & Fear to share incorrect information & & & & $\mathrm{x}$ & & Willem \& Buelens (2007) ; Pillai \& Min (2010) \\
\hline & I17 & Technophobia & $\mathrm{x}$ & $\mathrm{x}$ & $\mathrm{x}$ & $\mathrm{x}$ & $\mathrm{x}$ & Lin et al. (2012) \\
\hline \multirow{6}{*}{ Knowledge } & $\mathrm{K} 1$ & Causal ambiguity & & $\mathrm{x}$ & & $\mathrm{x}$ & $\mathrm{x}$ & Lin et al. (2008) \\
\hline & K2 & Non-validated knowledge & & $\mathrm{x}$ & & $\mathrm{x}$ & $\mathrm{x}$ & Lin et al. (2008); He et al. (2009) \\
\hline & K3 & Dominance in sharing explicit over tacit knowledge & $\mathrm{x}$ & & & $\mathrm{x}$ & & Riege (2005) \\
\hline & $\mathrm{K} 4$ & Human-embedded nature of knowledge & & & & $\mathrm{x}$ & & Cerchione et al. (2015)* \\
\hline & K5 & Difficulty in codifying tacit knowledge & $\mathrm{x}$ & $\mathrm{x}$ & $\mathrm{x}$ & $\mathrm{x}$ & $\mathrm{x}$ & Simonin $(2004)^{\dagger}$; Wagner \& Bukó $(2005)^{\dagger}$ \\
\hline & K6 & Overly technical terminology & & & & $\mathrm{x}$ & $\mathrm{x}$ & Koskinen (2005) \\
\hline
\end{tabular}

* SME-specific

†SC-related 
Poor knowledge sharing is often associated to the lack of balance of knowledge flows between the provider (source) and the knowledge seeker (Alavi and Leidner, 2001). The resulting knowledge asymmetries may be also the outcome of a rigid approach to knowledge transfer, based on teaching instead of learning (Becker, 2001). Issues in developing KM could also refer to lack of spaces to share or generate knowledge (Lin et al., 2012), poor physical work environment (Lin et al., 2012; Riege, 2005), or lack of intangible mechanisms, such as unscheduled meetings, informal seminars, or coffee breaks (e.g. He et al., 2009; Hutzschenreuter and Horstkotte, 2010).

Also, behavioural aspects play an important role in generating and diffusing knowledge. Difficult relationships among employees / business units / functions inhibit knowledge sharing (Bock et al., 2005; Szulanski, 1996), and close ties in communities could hamper knowledge creation because it is harder to generate new ideas for individuals that possess similar information and that belong to the same close-knit network (Robertson et al., 1996).

\section{Technological barriers}

Technology-driven approaches to KM often fail, and one of the reasons is that $\mathrm{KM}$ is a business process that relies on human interactions, which cannot be embedded into a technology (Ragab and Arisha, 2013). Although such an approach should be carefully avoided, technology is a well-known critical success factors for KM (Chong, 2006), and the lack of an appropriate technological infrastructure strongly affects KM adoption and development (Wong and Wong, 2011). Also, unrealistic expectations about KMSs, and the lack of communication and demonstration of the benefits in using these new systems over the previous ISs, hinder the whole KM process (Riege, 2005). The common perception of low trustfulness in system's security strengthens this effect (Kumar and Thondikulam 2006; Lin et al., 2012).

The introduction of KMSs entails challenging the typical hindrances linked to the adoption of a new IS, that in our case hamper KMD, for instance: lack of familiarity / experience or training concerning the new technology (Lin et al., 2012; Riege, 2005), low fit between the IS and the business processes (Brandon and Hollingshead, 2004), low integration between the new KMS and the other ISs because of lack of compatibility (Lin et al., 2012), or lack of technical support (Hutzschenreuter and Horstkotte, 2010). Some purport that KMSs could cage and inhibit learning (Cole, 1998), resulting in the knowledge being applied in inappropriate contexts (Alavi and Leidner, 2001). Moreover, knowledge retrieval mechanisms of such systems do not avoid information overload, increasing the likelihood of knowledge misuse because of too much readily available knowledge (Alavi and Leidner, 2001).

Technological barriers to KMD are not limited to KMSs. Also the lack of other technological sharing mechanisms, like telephones or computer networks, could impede KMD (He et al., 2009). In addition, failure in developing a transactive memory system - a system that supports groups in collectively encoding, storing, and retrieving knowledge - can hamper knowledge activities (Rosen et al., 2007).

\section{Cultural barriers}

Differences in national or ethnic background, values, beliefs or cultural characteristics are a common hindrance to KMD (Lin et al., 2008; Rosen et al., 2007; Wong and Wong, 2011). Misfits in organisational culture also include the lack of a shared meaning of KM activities (Beesley and Cooper, 2008) or the lack of a common attitude towards knowledge sharing (Hutzschenreuter and Horstkotte, 2010; Ling, 2011; Nätti and Ojasalo, 2008). Organisational culture should promote knowledge creation (Lang, 2001) and trust and commitment among the actors willing to share knowledge (Maqsood et al., 2007), also among SC members (Samuel et al., 2011; Spekman et al. 2002; Vithessonthi, 2008).

In order to be effective, and to avoid knowledge misuse, knowledge storage / retrieval and application should not overlook sufficient context detail (Alavi and Leidner, 2001), which should include cultural aspects.

\section{Individual barriers}

Individual behaviours and attitudes can be a relevant source of hurdles to the KM process. A common issue is the concern of causing job loss indirectly, by contributing to the company's KMS (Damodaran and Olphert, 2000; He et al., 2009), for instance because of a low awareness about KM practices. Employees can have unrealistic expectations about KM, and knowledge activities could be in conflict with their personal needs (Shin, 2004). Personal beliefs, pre-existing knowledge, and cognitive routines can impede search, absorption, and application of new knowledge (Alavi, 2000).

Fear is a common reason for distrust and reluctance of individuals towards KM, in example: fear of sharing incorrect (Pillai and Minin, 2010) or confidential (Paroutis and Saleh, 2009) information because of a low 
awareness of what knowledge must be shared (Levy et al., 2010; Lin et al., 2008); fear of being punished due to such mistakes (Davenport and Prusak, 1998); or simply fear that information sharing entails losing the individual advantage, benefiting the other whom knowledge was shared with (Hislop, 2009; Renzl, 2008; Shaw and Edwards, 2005). Trustfulness plays a similar role, since lack of trust in people (Riege, 2005; Rosen et al., 2007), in knowledge (He et al., 2008), or in the source of such knowledge (Davenport and Prusak, 2008; Lin et al., 2008) heavily influence knowledge practices.

Differences in experience, age, gender, and education levels are a strong impediment to KMD (Riege, 2005). Such differences might be associated with other barriers that can hinder knowledge transfer and application, like lack of absorptive capability (Chou et al., 2007; Szulanski, 1996), of retentive capacity (Lin et al., 2010), or of adequate communication, interpersonal, and computer skills (Hutzschenreuter and Horstkotte, 2010; Riege, 2005). In some cases, old age or low levels of education could be related to several forms of technophobia, which could interfere with KMSs diffusion and with the introduction of the KM process (Lin et al., 2010).

Knowledge diffusion practices may also be hampered by contingent factors, like the lack of time or opportunity to share knowledge (Davenport and Prusak, 1998; Lin et al., 2010) or to put it in a form suitable for being shared (Levy et al., 2010).

\section{Knowledge barriers}

Knowledge characteristics represent an intrinsic barrier to KM. For instance, a common barrier to knowledge flow is the causal ambiguity, that is, the difficulty to determine the reasons for success or failure in replicating a capability or actions which were previously performed by acting upon specific knowledge (Lin et al., 2008). This is likely linked to the decision to rely on non-validated knowledge, which is knowledge that lacks a record of its past usefulness, leading to mistrust towards it by the recipient (He et al., 2009; Lin et al., 2008).

In general, firms share more explicit than tacit knowledge (Riege, 2005), hindering and inhibiting KM activities. Instead, increasing the awareness that tacit knowledge is hard to transfer, companies should strive to point out the need to share it (Nonaka and Takeuchi, 1995). Nevertheless, this is hampered by the nature of the tacit knowledge, which is often human-embedded, in particular in SMEs (Cerchione et al., 2015), and hard-to-codify (Simonin, 2004; Wagner and Bukó, 2005).

\section{Results and discussion}

The context we took in consideration is a small-to-medium Mediterranean port that is experiencing a positive growth trend: in 2016, its annual container traffic surpassed 800000 units. This port supports its most important processes and activities by means of a PCS, i.e. import, export, interface with the customs system, national and community cabotage, certified weighing. According to the current development plan, the PCS will be connected to a new monitoring platform that shall control the port area, integrating the operational databases with different kinds of structured and unstructured data.

Through the FG, we assessed the relevance of the six clusters of barriers to KM in this PCS-enabled port. In accordance with their relevance to maritime operations within the context we considered, the six clusters were ranked as follows: Strategy, Technology, Organisation, Culture, Individual, and Knowledge. Strategy, Technology, and Organisation clusters were found to be more important than Culture, Individual, and Knowledge clusters. Hence, the former were labelled as primary, while the latter as secondary.

Strategic barriers are the most relevant ones. Most actors of the port community are small-sized, and struggled to fund the investment for developing or modifying their ISs for connecting to the PCS and, thus, for sharing and receiving information. Moreover, they were forced to change their strategies and to speed up their decision-making because, since the PCS enables near real-time information sharing, such information has to be exploited quickly, otherwise its usefulness could drastically decrease. Despite this, ever since the PCS had gone into its onward/upward phase, port operators have claimed that the benefits from the increased information availability have been stronger than expected. Nonetheless, most port stakeholders are still unaware of how the increased availability could be framed within an overall KM effort. This lack of awareness is directly linked to the low priority that the PA - i.e. the leading port actor - has currently assigned to $\mathrm{KM}$ initiatives.

The main reason for this policy is that the development of the port has mainly been technology-driven, although it is gradually shifting towards a more strategy-driven direction. This highlights a contrast between strategical and technological barriers. The PA exploits the PCS via a Software-as-as-Service cloud service 
model. Both the provider of the PCS services and the ICT function of the PA have pushed for a technologydriven development of the port. Differently, the heads of the PA has started to contain this technological drift for better framing the port ICT projects within a well-specified business direction. This turnaround made the strategic barriers the most critical ones, as the PA is actively trying to figure out how to extract knowledge from the available data, although it should structure a more extensive KM initiative by actively involving the whole port community.

Technological barriers were the second most critical ones. Concerns about data security and privacy hampered the PCS adoption and development. Several small operators did not perceive it as a problem: they were used to manage their processes by paper and, ever since they developed their ISs for connecting to the PCS, they have not complained about privacy issues. Instead, bigger operators like port terminals, which manage larger data sets, were reluctant towards the project. The PA coped with these concerns by organising and fostering training events for increasing the awareness about how the PCS works, and has offered a dedicated help desk. These solutions tackled the security and privacy barriers and the hindrances related to the IS use (T6, T7, T8, T9) strongly, but the worries were not completely overcome. They came back in the limelight with the introduction of the certified weighing functionality, since several actors did not want to share the weights of their cargos. Thus, it was necessary to modify the reading permissions within the port databases.

Organisational barriers were ranked as the third most relevant ones. In order to better exploit the PCS, some port operators needed to redefine the internal and external communication flow. For instance, on one occasion, a software developer working for a port terminal detected a problem in the interface between their IS and the PCS, and this issue could have jeopardized the data sharing security. The developer reported it to the PA directly while, before the implementation of the PCS, this warning should have been communicated in a more formal way and through the head of the IT department. Instead, the terminal decided to foster the information diffusion through a less hierarchical structure and a more horizontal communication flow.

Although the organisational structure of the port community is different from the one of a firm, the lack of an incentive system is a deep-felt issue as well. The port stakeholders know that the data they submit to and through the PCS are collected for managerial purposes, but they do it only for keeping their operational efficiency intact. The database of the PCS suffers from some data inconsistencies because, often, the submitted data are incomplete, and there is not any form of incentive that entices people to put more attention during the data entry.

The other three clusters of KM barriers - Culture, Individual, Knowledge - were considered as secondary. Despite the business relationships between the PA under analysis and its foreign partners in North Africa, which have different habits and organisational culture, the cultural barriers were not deemed as a priority. There are two possible reasons for this line of thought. First, port communities are rather closed, and led by the PAs which usually define the main port development directions. As the balance of power is strongly in favour of the PA shifts in the organisational culture of the port community are often imposed, and they could be the indirect consequence of the transposition of a directive. Second, the port under analysis is small-tomedium sized. Also, most port stakeholders, such as the freight forwarders, are not really structured, and their small dimension makes cultural issues less relevant.

The individual barriers were not considered as relevant because most human resources working for the port community are not truly aware about the reasons behind the centralized data collection and processing. They prefer to focus on their operations only, within their "comfort zone". Yet, such a behaviour leads to overlook the KM dynamics and, at the same time, it exacerbates the barriers related to the individual risk aversion (e.g. I3, I5, I6, I7). Even though the PA has planned and developed specific interventions for mitigating this phenomenon, these individual positions towards KM initiatives are affected by the lack of organisational and business structuredness of several small port stakeholders. In particular, Technophobia (I17) is still deeplyrooted in some port actors, and it is linked to the perception of losing control over the information. Thus, some people - a minority - prefer to share incomplete information if they have doubts concerning the related knowledge development activities.

Finally, knowledge barriers were judged as low-pertinent since the PCS gathers and arranges structured data, mostly enabling the potential creation of explicit knowledge only. Currently, the PA is developing an advanced network of sensors across all the port area for collecting semi-structured data too, for purposes ranging from environmental and logistics monitoring to security. This innovation, which comes under the IoT paradigm, could change the priority of the clusters of KM barriers. Knowledge barriers could assume more relevance because the PA should formulate appropriate business propositions considering the data 
heterogeneity, challenging the issues of creating, encoding, and validating knowledge extracted from different forms of data.

\section{Conclusions}

Our work presents three scientific contributions. First, literature could benefit from our up-to-date in-depth systematic literature review about barriers to KM. In particular, it integrates the work by Cerchione et al. (2015) by extending their review to companies bigger than SMEs.

Second, it is an answer to the suggestion by Cerchione and Esposito (2016) to deepen the barriers to KMA in SC. It enriches the barriers singled out and prioritised by Patil and Kant (2014b), and widens their analysis by considering both KMA and KMD. It is worth noting that the ranking of the six clusters of barriers stemmed from a PCS-enabled port, which does not necessarily coincide with a SC. A PCS serves a port community, which is rather different from a firm because it encompasses different stakeholders that act in different nodes of the SC and that may have competing objectives. Thus, for a port community, barriers hampering KM within the boundaries of a single stakeholder - i.e. individual or cultural barriers - could be less important, while strategical and technological aspects may overcome these constraints because they require interconnection and interaction with other actors. Consequently, some barriers may become more relevant than others in a more structured context, where the average size of the operators belonging to the port community is bigger.

Third, this work addresses two topical and underexplored research areas: logistic KM and PCS-enabled maritime operations. About logistic KM, the results increase the awareness of KM barriers, and provide a ranking of priority for tackling the six clusters in a multidisciplinary context, filling the corresponding literature gap pointed out by Evangelista and Durst (2015). As regards maritime operations, this paper is consistent with the claim, by Eon-Seong and Dong-Wook (2010), about the relevance of KM strategy to maritime logistics. Furthermore, to our best knowledge, this is the first contribution deepening KM in a PCSenabled context. It frames PCSs as a KMS, which is in line with the relationship, hypothesised by van Baalen et al. (2008), between PCSs and port communities in meeting the demands of global SCs.

From a practitioner standpoint, this paper suggests the most important areas which should be appropriately addressed in undertaking KM initiatives in PCS-supported port communities. A further deepening of these areas may lead to more efficient KM activities, and it may contribute to define sounder business cases and business directions for KM efforts towards PCS-enabled port logistics services.

The outcomes we presented can be a major input for prioritising and tackling the hindrances to KM initiatives in PCS-enabled ports. For instance, the shift towards the more strategy-driven development, which the port community we analysed is experiencing, is a way for coping with the Strategy cluster. In this meaning, the interventions by the PA should elucidate what the KM process consists in, which benefits it could provide, how each port actor could benefit from it, how and why port stakeholders should contribute to it. These actions should address the whole port community through a holistic KM effort, and should be actively supported by the PA top management.

A first attempt in overcoming the organisational barriers could consists in developing an incentive system for persuading the port stakeholders to be proactively involved in the KM process. Such a solution could proscribe knowledge hoarding (O4) and favour knowledge sharing. The incentive system may reduce the need to resort to position-based status and formal power in fostering the KM activities (O14), and may facilitate the learning effect (O15) by supporting a systematic analysis of the knowledge extractable from the past mistakes.

A potential solution to the Technology cluster may be to settle the barriers related to the IS use - see the Results and discussion section. For instance, on one side, specific activities for improving the awareness of the PCS dynamics across the main stakeholders could clarify the purposes of collecting and centralising the data in a KM perspective. On the other side, the data from the PCS shall be integrated with the semistructured data from the sensors network and with the unstructured data from the monitoring platform, and the ICS function of the PA shall enable this interoperability. The FG we run pointed out that the PCS we considered may be a source of streamlined structured data that, if integrated with the less structured data from the monitoring platform, might set up the basis for a possible Big Data exploitation. In a wider perspective, the current ICT-enabled collaborative trend in maritime SCs, contextualized among different PCS-enabled port areas, may enable conjoint forms of innovation and coordination, bringing logistic KM activities to a greater scale. 
This work is not free from some limitations. On one hand, a FG might provide only an initial insight about which barriers to KM may be the most relevant ones in the PCS-enabled context. On the other hand, evidences from a single PA are limited, and other port areas should be investigated. Hence, we propose three possible venues for further research. First, it could be useful to design and conduct a survey for collecting quantitative data about the classification we presented. These data could be used to streamline the total number of barriers and to define classification sub-criteria for instance through a Principal Component Analysis. Second, in order to improve our findings, it could be useful to broaden the scope of the qualitative inquiry we conducted to other port areas through a case study approach. Finally, a third opportunity could consist in going beyond the awareness of the logistic KM barriers we analysed, and to propose how to concretely overcome them in a port context drawing from the practical suggestions we already pointed out.

\section{References}

Ahmad, N. and Daghfous, A. (2010), "Knowledge sharing through inter-organizational knowledge networks: Challenges and opportunities in the United Arab Emirates", European Business Review, Vol. 22 No. 2, pp. 153174.

Ahn, H.J., Lee, H.J., Cho, K. and Park, S.J. (2005), "Utilizing knowledge context in virtual collaborative work", Decision Support Systems, Vol. 39 No. 4, pp. 563-582.

Al-Mutawah, K., Lee, V. and Cheung, Y. (2009), "A new multi-agent system framework for tacit knowledge management in manufacturing supply chains”, Journal of Intelligent Manufacturing, Vol. 20 No. 5, pp. 593-610.

Alavi, M. (2000), "Managing Organizational Knowledge”, in Zmud, R.W. (Ed.), Framing the Domains of IT Management Research: Glimpsing the Future through the Past, Pinnaflex Educational Resources, Cincinnati, $\mathrm{OH}$.

Alavi, M., Kayworth, T.R. and Leidner, D.E. (2005), “An Empirical Examination of the Influence of Organizational Culture on Knowledge Management Practices”, Journal of Management Information Systems, Vol. 22 No. 3, pp. $191-224$.

Alavi, M. and Leidner, D.E. (2001), "Review: Knowledge anagement and knowledge management systems: Conceptual foundations and research issues", MIS Quarterly: Management Information Systems, Vol. 25 No. 1, pp. $107-136$.

Aydogdu, Y. V. and Aksoy, S. (2015), “A study on quantitative benefits of port community systems", Maritime Policy and Management, Vol. 42 No. 1, pp. 1-10.

Aziz, N. and Sparrow, J. (2011), "Patterns of gaining and sharing of knowledge about customers: A study of an Express Parcel Delivery Company”, Knowledge Management Research and Practice, Vol. 9 No. 1, pp. $29-47$.

van Baalen, P., Zuidwijk, R. and van Nunen, J. (2008), "Port Inter-Organizational Information Systems: Capabilities to Service Global Supply Chains", Foundations \& Trends in Technology, Information \& Operations Management, Vol. 2 No. 2/3, pp. 81-241.

Bandyopadhyay, S. and Pathak, P. (2007), "Knowledge sharing and cooperation in outsourcing projects - A game theoretic analysis", Decision Support Systems, Vol. 43 No. 2, pp. 349-358.

Baron, M. and Mathieu, H. (2013), “PCS interoperability in Europe: a market for PCS operators?”, International Journal of Logistics Management, Vol. 24 No. 1, pp. 117-129.

Becker, M. (2001), "Managing dispersed knowledge: Organizational problems, managerial strategies, and their effectiveness", Journal of Management Studies, Vol. 38 No. 7, pp. 1036-1051.

Beesley, L.G.A. and Cooper, C. (2008), "Defining knowledge management (KM) activities: Towards consensus", Journal of Knowledge Management, Vol. 12 No. 3, pp. 48-62.

Bhatt, G.D. (2000), “Organizing knowledge in the knowledge development cycle”, Journal of Knowledge Management, Vol. 4 No. 1, pp. 15-26.

Blumenberg, S., Wagner, H.T. and Beimborn, D. (2009), "Knowledge transfer processes in IT outsourcing relationships and their impact on shared knowledge and outsourcing performance", International Journal of Information Management, Vol. 29 No. 5, pp. 342-352.

Bock, G.-W., Zmud, R.W., Kim, Y.-G. and Lee, J.-N. (2005), "Behavioral Intention Formation in Knowledge Sharing : Examining the Roles of Extrinsic Motivators, Social-Psychological Forces , and Organizational Climate", MIS Quarterly: Management Information Systems, Vol. 29 No. 1, pp. 87-111.

Brandon, D.P. and Hollingshead, A.B. (2004), “Transactive memory systems in organizations: Matching tasks, expertise, and people”, Organization Science, Vol. 15 No. 6, pp. 633-644.

Brown, J.S. and Duguid, P. (1998), “Organizing Knowledge”, California Management Review, Vol. 40 No. 3, pp. $90-$ 111.

Cai, S., Goh, M., De Souza, R. and Li, G. (2013), "Knowledge sharing in collaborative supply chains: twin effects of trust and power", International Journal of Production Research, Vol. 51 No. 7, pp. 2060-2076. 
Carlan, V., Sys, C. and Vanelslander, T. (2016), "How port community systems can contribute to port competitiveness: Developing a cost-benefit framework", Research in Transportation Business and Management, Vol. 19, pp. 5164.

Cerchione, R. and Esposito, E. (2016), “A systematic review of supply chain knowledge management research: State of the art and research opportunities”, International Journal of Production Economics, Vol. 182, pp. $276-292$.

Cerchione, R., Esposito, E. and Spadaro, M.R. (2015), "The spread of knowledge management in SMEs: A scenario in evolution", Sustainability (Switzerland), Vol. 7 No. 8, pp. 10210-10232.

Chen, J., Sun, P.Y.T. and McQueen, R.J. (2010), "The impact of national cultures on structured knowledge transfer", Journal of Knowledge Management, Vol. 14 No. 2, pp. 228-242.

Cheng, J.-H., Yeh, C.-H. and Tu, C.-W. (2008), “Trust and knowledge sharing in green supply chains”, Supply Chain Management, Vol. 13 No. 4, pp. 283-295.

Chong, S.C. (2006), "KM critical success factors: A comparison of perceived importance versus implementation in Malaysian ICT companies", The Learning Organization, Vol. 13 No. 3, pp. 230-256.

Chou, P. Ben and Passerini, K. (2009), "Intellectual property rights and knowledge sharing across countries", Journal of Knowledge Management, Vol. 13 No. 5, pp. 331-344.

Chou, T.C., Chang, P.L., Cheng, Y.P. and Tsai, C.T. (2007), “A path model linking organizational knowledge attributes, information processing capabilities, and perceived usability", Information and Management, Vol. 44 No. 4, pp. 408-417.

Cole, R.E. (1998), “Introduction”, California Management Review, Vol. 40 No. 3, pp. 15-21.

Damodaran, L. and Olphert, W. (2000), "Barriers and facilitators to the use of knowledge management systems", Behaviour Information Technology, Vol. 19 No. 6, pp. 405-413.

Davenport, T.H. and Prusak, L. (1998), Working Knowledge: How Organizations Manage What They Know, Harvard Business Press, available at:http://doi.org/10.1109/EMR.2003.1267012.

Eon-Seong, L. and Dong-Wook, S. (2010), "Knowledge management for maritime logistics value: Discussing conceptual issues", Maritime Policy and Management, Vol. 37 No. 6, pp. 563-583.

Esper, T.L., Ellinger, A.E., Stank, T.P., Flint, D.J. and Moon, M. (2010), “Demand and supply integration: A conceptual framework of value creation through knowledge management", Journal of the Academy of Marketing Science, Vol. 38 No. 1, pp. 5-18.

Evangelista, P. and Durst, S. (2015), "Knowledge management in environmental sustainability practices of third-party logistics service providers", VINE, Vol. 45 No. 4, pp. 509-529.

Fan, J., Han, F. and Liu, H. (2014), “Challenges of Big Data analysis”, National Science Review, Vol. 1 No. 2, pp. 293314.

Fernández, P., Santana, J.M., Ortega, S., Trujillo, A., Suárez, J.P., Domínguez, C., Santana, J., et al. (2016), "Smartport: A platform for sensor data monitoring in a seaport based on FIWARE", Sensors (Switzerland), Vol. 16 No. 3 , available at:http://doi.org/10.3390/s16030417.

Fletcher, L. and Polychronakis, Y.E. (2007), "Capturing knowledge management in the supply chain”, EuroMed Journal of Business, Vol. 2 No. 2, pp. 191-207.

Fugate, B.S., Autry, C.W., Davis-Sramek, B. and Germain, R.N. (2012), "Does knowledge management facilitate logistics-based differentiation? the effect of global manufacturing reach", International Journal of Production Economics, Vol. 139 No. 2, pp. 496-509.

Fugate, B.S., Stank, T.P. and Mentzer, J.T. (2009), "Linking improved knowledge management to operational and organizational performance”, Journal of Operations Management, Vol. 27 No. 3, pp. 247-264.

Garcia-perez, A. and Ayres, R. (2010), "Wikifailure the Limitation of Technology for Knowledge Sharing”, Electronic Journal of Knowledge Management, Vol. 8 No. 1, pp. 43-52.

Gunasekaran, A. and Ngai, E.W.T. (2004), "Information systems in supply chain integration and management", European Journal of Operational Research, Vol. 159 No. 2 SPEC. ISS., pp. 269-295.

He, W., Qiao, Q. and Wei, K.K. (2009), "Social relationship and its role in knowledge management systems usage", Information and Management, Vol. 46 No. 3, pp. 175-180.

Heilig, L. and Voß, S. (2017), "Information systems in seaports: a categorization and overview”, Information Technology and Management, Springer US, Vol. 18 No. 3, pp. 179-201.

Henry, R.M., McCray, G.E., Purvis, R.L. and Roberts, T.L. (2007), “Exploiting organizational knowledge in developing IS project cost and schedule estimates: An empirical study", Information and Management, Vol. 44 No. 6, pp. 598-612.

Hislop, D. (2009), Knowledge Management in Organizations: A Critical Introduction, 2nd editio., Oxford University Press, New York. 
Hult, G.T.M., Ketchen Jr, D.J. and Slater, S.F. (2004), "Information Processing, Knowledge Development, and Strategic Supply Chain Performance”, Academy of Management Journal, Vol. 47 No. 2, pp. 241-253.

Hutzschenreuter, T. and Horstkotte, J. (2010), "Knowledge transfer to partners : a firm level perspective", Journal of Knowledge Management, Vol. 14 No. 3, pp. 428-448.

Joshi, K.D., Sarker, S. and Sarker, S. (2007), "Knowledge transfer within information systems development teams: Examining the role of knowledge source attributes", Decision Support Systems, Vol. 43 No. 2, pp. 322-335.

Kasper, H., Mühlbacher, J. and Müller, B. (2008), "Intra-organizational knowledge sharing in MNCs depending on the degree of decentralization and communities of practice", Journal of Global Business \& Technology, Vol. 4 No. 1, pp. 59-68.

Kitzinger, J. (1994), "The methodology of Focus Groups: the importance of interaction between research participants", Sociology of Health \& Illness, Vol. 16 No. 1, pp. 103-121.

Kitzinger, J. (1995), “Introducing focus groups”, British Medical Journal, Vol. 311 No. 7000, pp. $299-302$.

Koskinen, K.U. (2005), "Metaphoric boundary objects as co-ordinating mechanisms in the knowledge sharing of innovation processes", European Journal of Innovation Management, Vol. 8 No. 3, pp. 323-335.

Kumar, S. and Thondikulam, G. (2006), "Knowledge management in a collaborative business framework", Information Knowledge Systems Management, Vol. 12 No. 5, pp. 171-187.

Lam, A. and Lambermont-Ford, J.-P. (2010), "Knowledge sharing in organisational contexts: a motivation-based perspective [Electronic version]", Journal of Knowledge Management, Vol. 14 No. 1, pp. 51-66.

Lang, J.C. (2001), "Managerial concerns in knowledge management", Journal of Knowledge Management, Vol. 5 No. 1, pp. 43-59.

Levy, M., Hadar, I., Greenspan, S. and Hadar, E. (2010), “Uncovering cultural perceptions and barriers during knowledge audit", Journal of Knowledge Management, Vol. 14 No. 1, pp. 114-127.

Liang, G.S., Ding, J.F. and Wang, C.K. (2012), “Applying fuzzy quality function deployment to prioritize solutions of knowledge management for an international port in Taiwan”, Knowledge-Based Systems, Vol. 33, pp. 83-91.

Lin, C., Tan, B. and Chang, S. (2008), “An exploratory model of knowledge flow barriers within healthcare organizations", Information and Management, Vol. 45 No. 5, pp. 331-339.

Lin, C., Wu, J.-C. and Yen, D.C. (2012), "Exploring barriers to knowledge flow at different knowledge management maturity stages", Information and Management, Vol. 49 No. 1, pp. 10-23.

Ling, C.T.N. (2011), “Culture and trust in fostering knowledge-sharing.”, Electronic Journal of Knowledge Management, Vol. 9 No. 4, pp. 328-339.

Malhotra, A., Gosain, S. and El Sawy, O.A. (2005), “Absorptive capacity configurations in supply chains: gearing for partner-enabled market knowledge creation.”, MIS Quarterly: Management Information Systems, Vol. 29 No. 1, pp. $145-187$.

Maqsood, T., Walker, D. and Finegan, A. (2007), "Extending the 'knowledge advantage': creating learning chains”, The Learning Organization, Vol. 14 No. 2, pp. 123-141.

Meersman, H., van de Voorde, E. and Vanelslander, T. (2016), "Port competitiveness now and in the future: What are the issues and challenges?", Research in Transportation Business and Management, Vol. 19, pp. 1-3.

Miles, M.B., Huberman, A.M. and Saldaña, J. (2013), Qualitative Data Analysis: A Methods Sourcebook, 3rd ed., SAGE Inc.

Mintzberg, H. (1993), Structure in Fives: Designing Effective Organizations, Prentice Hall College Div.

Myers, M.B. and Cheung, M. (2008), "Sharing global supply chain knowledge”, MIT Sloan Management Review, Vol. 49 No. 4, pp. 67-73.

Nätti, S. and Ojasalo, J. (2008), "Loose coupling as an inhibitor of internal customer knowledge transfer: findings from an empirical study in B-to-B professional services", Journal of Business \& Industrial Marketing, Vol. 23 No. 3 , pp. 213-223.

Nonaka, I. and Takeuchi, H. (1995), The Knowledge-Creating Company: How Japanese Companies Create the Dynamics of Innovation, Oxford Uni.

Norbis, M., Meixell, M.J. and Tuggle, F.D. (2013), "Modelling security in the maritime supply chain using knowledge constructs", International Journal of Logistics Systems and Management, Vol. 15 No. 4, pp. 359-381.

Nunes, M.B., Annansingh, F., Eaglestone, B. and Wakefield, R. (2006), "Knowledge management issues in knowledgeintensive SMEs", Journal of Documentation, Vol. 62 No. 1, pp. 101-119.

Paroutis, S. and Saleh, A.A. (2009), "Determinants of knowledge sharing using Web 2.0 technologies", Journal of Knowledge Management, Vol. 13 No. 4, pp. 52-63.

Patil, S.K. and Kant, R. (2014a), “A fuzzy AHP-TOPSIS framework for ranking the solutions of Knowledge Management adoption in Supply Chain to overcome its barriers", Expert Systems with Applications, Vol. 41 No. 
2, pp. 679-693.

Patil, S.K. and Kant, R. (2014b), "Ranking the barriers of knowledge management adoption in supply chain using fuzzy AHP method", International Journal of Business Innovation and Research, Vol. 8 No. 1, pp. 52-75.

Pillai, K.G. and Min, S. (2010), “A firm's capability to calibrate supply chain knowledge-Antecedents and consequences", Industrial Marketing Management, Vol. 39 No. 8, pp. 1365-1375.

PORTEL. (2009), Inventory of Port Single Windows and Port Community Systems, available at: http://www.eskema.eu/DownloadFile.aspx?tableName=tblSubjectArticles\&field=PDF Filename\&idField=subjectArticleID\&id=231.

Ragab, M.A.F. and Arisha, A. (2013), "Knowledge Management and Measurement: A Critical Review Abstract”, Journal of Knowledge Management, Vol. 17 No. 6, pp. 873-901.

Raisinghani, M.S. and Meade, L.L. (2005), "Strategic decisions in supply-chain intelligence using knowledge management: An analytic-network-process framework", Supply Chain Management: An International Journal, Vol. 10 No. 2, pp. 114-121.

Renzl, B. (2008), "Trust in management and knowledge sharing: The mediating effects of fear and knowledge documentation", Omega, Vol. 36 No. 2, pp. 206-220.

Riege, A. (2005), “Three-dozen knowledge-sharing barriers managers must consider”, Journal of Knowledge Management, Vol. 9 No. 3, pp. 18-35.

Robertson, M., Swan, J. and Newell, S. (1996), "The role of networks in the diffusion of technological innovation", Journal of Management Studies, Vol. 33 No. 3, pp. 333-359.

Rosen, B., Furst, S. and Blackburn, R. (2007), "Overcoming barriers to knowledge sharing in virtual teams", Organizational Dynamics, Vol. 36 No. 3, pp. 259-273.

Samuel, K.E., Goury, M.-L., Gunasekaran, A. and Spalanzani, A. (2011), "Knowledge management in supply chain: An empirical study from France", The Journal of Strategic Information Systems, Vol. 20 No. 3, pp. $283-306$.

Schein, E.H. (1990), “Organizational Culture”, American Psychologist, Vol. 45 No. 2, pp. 109-119.

Shaw, D. and Edwards, J.S. (2005), "Building user commitment to implementing a knowledge management strategy", Information and Management, Vol. 42 No. 7, pp. 977-988.

Shih, S.C., Hsu, S.H.Y., Zhu, Z. and Balasubramanian, S.K. (2012), "Knowledge sharing-A key role in the downstream supply chain”, Information and Management, Vol. 49 No. 2, pp. 70-80.

Shin, M. (2004), “A framework for evaluating economics of knowledge management systems”, Information \& Management, Vol. 42 No. 1, pp. 179-196.

Simonin, B.L. (2004), “An empirical investigation of the process of knowledge transfer in international strategic alliances", Journal of International Business Studies, Vol. 35 No. 5, pp. 407-427.

Spekman, R.E., Spear, J. and Kamauff, J. (2002), "Supply chain competency: learning as a key component”, Supply Chain Management: An International Journal, Vol. 7 No. 1, pp. 41-55.

Szulanski, G. (1996), "Exploring internal stickiness: Impediments to the transfer of best practice within the firm", Strategic Management Journal, Vol. 17, pp. 27-43.

Vithessonthi, C. (2008), "Social interaction and knowledge sharing behaviour in multinational corporations", The Business Review, Vol. 12 No. 2, pp. 324-331.

Wagner, S.M. and Bukó, C. (2005), “An empirical investigation of knowledge-sharing in networks”, Journal of Supply Chain Management, Vol. 41 No. 4, pp. 17-31.

Waller, M.A. and Fawcett, S.E. (2013a), "Data Science , Predictive Analytics , and Big Data: A Revolution That Will Transform Supply Chain Design and Management”, Journal of Business Logistics, Vol. 34 No. 2, pp. 77-84.

Waller, M.A. and Fawcett, S.E. (2013b), "Click Here for a Data Scientist: Big Data, Predictive Analytics, and Theory Development in the Era of a Maker Movement Supply Chain.”, Journal of Business Logistics, Vol. 34 No. 4, pp. 249-252.

Wang, D., Su, Z. and Yang, D. (2011), “Organizational culture and knowledge creation capability”, Journal of Knowledge Management, Vol. 15 No. 3, pp. 363-373.

Wang, G., Gunasekaran, A., Ngai, E.W.T. and Papadopoulos, T. (2016), "Big data analytics in logistics and supply chain management: Certain investigations for research and applications", International Journal of Production Economics, Vol. 176, pp. 98-110.

Watts, M. and Ebbutt, D. (1987), "More than the Sum of the Parts: research methods in group interviewing", British Educational Research Journal, Vol. 13 No. 1, pp. 25-34.

Webster, J. and Watson, R.T. (2002), “Analyzing the Past to Prepare for the Future: Writing a Literature Review.”, MIS Quarterly, Vol. 26 No. 2, pp. xiii-xxiii.

Wiig, K.M. (1997), “Knowledge management: Where did it come from and where will it go?”, Expert Systems with 
Applications, Vol. 13 No. 1, pp. 1-14.

Willem, A. and Buelens, M. (2007), "Knowledge sharing in public sector organizations: The effect of organizational characteristics on interdepartmental knowledge sharing", Journal of Public Administration Research and Theory, Vol. 17 No. 4, pp. 581-606.

Wong, K.Y. and Aspinwall, E. (2005), "An empirical study of the important factors for knowledge-management adoption in the SME sector", Journal of Knowledge Management, Vol. 9 No. 3, pp. 64-82.

Wong, K.Y. and Aspinwall, E. (2006), "Development of a knowledge management initiative and system: A case study", Expert Systems with Applications, Vol. 30 No. 4, pp. 633-641.

Wong, W.P. and Wong, K.Y. (2011), "Supply chain management, knowledge management capability, and their linkages towards firm performance", Business Process Management Journal, Vol. 17 No. 6, pp. 940-964.

Zhao, J., De Pablos, P.O. and Qi, Z. (2012), "Enterprise knowledge management model based on China's practice and case study", Computers in Human Behavior, Vol. 28 No. 2, pp. 324-330.

\section{Appendix}

Table A.1, extracted and re-arranged from a report by PORTEL (2009) as part of the SKEMA European project - see http://www.skematransport.eu/ for further detail - contains examples of activities performed by real PCSs. Some PCSs, like the one in Hamburg, offer functionalities that go beyond the port area and that support multimodal transport.

Table A.1 Examples of PCS functions

\begin{tabular}{|c|c|}
\hline Port & Transactions, function and / or documents \\
\hline Antwerp & $\begin{array}{l}\text { Cargo information; } \\
\text { "Crossroad" bank central database; }\end{array}$ \\
\hline Bordeaux & $\begin{array}{l}\text { Cargo declaration; } \\
\text { Freight and vessels taxes (port and customs) declaration; } \\
\text { Customs clearance; }\end{array}$ \\
\hline Copenhagen Malmö & $\begin{array}{l}\text { Reporting of cargo operations from ship operators; relaying of cargo handling } \\
\text { information to ship operators; } \\
\text { Reporting of expected cargo from cargo operators; relaying of cargo handling } \\
\text { information to cargo operators; }\end{array}$ \\
\hline Esbjerg & Report of ship arrival and departure to the Royal Danish Navy SafeSeaNet; \\
\hline \multirow{4}{*}{ Hamburg } & $\begin{array}{l}\text { Customs clearance procedures: } \\
\text { - } \quad \text { ATLAS Export System (level 1, level 2); } \\
\text { - Surety bond management; } \\
\text { - Single customs declaration; } \\
\text { - } \quad \text { Customs summary (supplementary customs declaration); } \\
\text { - Summary declaration; } \\
\text { - Simplified procedures; } \\
\text { - Transit (NCTS), dispatch and receipt; } \\
\text { - } \quad \text { Customs warehouse; } \\
\text { - Inward processing; } \\
\text { - } \quad \text { Processing under customs control; }\end{array}$ \\
\hline & $\begin{array}{l}\text { Creation and printing of all current versions of Single Administrative } \\
\text { Documents: } \\
\text { - EZT (electronic customs tariff); } \\
\text { - Ten-year automatic archiving; } \\
\text { - Box interface for data integration; }\end{array}$ \\
\hline & $\begin{array}{l}\text { Railway operations: } \\
\text { - Receive and process waybills; } \\
\text { - Transport orders; } \\
\text { - Status information; }\end{array}$ \\
\hline & $\begin{array}{l}\text { Transportation and process of containers operations: } \\
\text { - Transport orders and clearances; } \\
\text { - Comparison and calculation of tariffs; } \\
\text { - Calculation of distances for road and rail; } \\
\text { - Creation of invoices; }\end{array}$ \\
\hline
\end{tabular}


- Connection to accounting systems;

- Creation of forms and lists;

- Generation of statistics;

- Forthcoming transport notifications;

- Notification of errors or changes in the basic conditions, such as any delays or missing papers (clearance);

Dangerous goods notifications:

- Stowage for dangerous cargo;

- Segregation for dangerous cargo;

- Accident leaflets;

Receipt of Manifests (electronic and manual);

Import Customs Declarations \& Clearance;

Export Customs declarations;

Export clearance;

Simplified UK Transit;

Manifest Write off;

Transhipment processing;

Southampton Gate Pass;

Landed \& loaded messages to shipping lines;

Gate messages to shipping lines;

Receipt of export booking info (electronic and manual);

Vehicle Booking;

Central Help Desk;

Ad hoc reports;

Intrastat declarations;

Maritime Statistical declarations; 